\title{
The Removal of Lead, Copper and Zinc from Industrial Wastewater Using Grape Fruit Peels
}

\author{
Sufyan M. Shartooh* Hussain Sh. Gabur Omar S. Mahmood \\ Directorate of Waste Treatment and Destruction \\ Ministry of Science and Technology \\ Baghdad \\ *Email: dralwaisi@yahoo.com
}

(Received 8/4/2013;Accepted 9/9/2013)

\begin{abstract}
The current study was designed for using grape fruit peels (Citrus paradise) to remove lead, copper and zinc from industrial wastewater. Three forms of these peels (fresh, dried small pieces and powder) were tested under some environmental factors such as $\mathrm{pH}$, temperature and contact time. Current data show that grape fruit peels are capable of removing lead, copper and zinc ions with a significant capacity. Furthermore, the powder of grape fruit peels had a highest capability in removing all lead, copper and zinc ions followed by fresh peels whilst dried peels had the lowest bioremoving capacity again for all metals under test. The highest capacity was for lead then copper and finally zinc. All these data were significantly $\left(\mathrm{LSD}_{\text {peel forms }}=3.349 \mathrm{mg} / \mathrm{l}\right)$ varied. However, some examined factors were found to have significant impacts upon the bioremoval capacity of grape fruit peels such as $\mathrm{pH}$, temperature, and contact time where best biosorption capacity was found at $\mathrm{pH}$ 4 , at temperature $50 \mathrm{C}^{\circ}$ and contact time of 1 hour. It is true that grape fruit peels varied significantly in case of metal ions and increasing examined factor $(\mathrm{pH}$, temperature, and contact time). The fourier transform infrared spectroscopy analysis (FTIR) illustrated that hydroxyl, carboxyl and carbonyl groups were the major binding sites for $\mathrm{Pb}, \mathrm{Cu}$ and $\mathrm{Zn}$ ions by grape fruit peels.
\end{abstract}

Keywords: Grape fruit peels, biosorption, Lead, Copper, Zinc, FTIR.
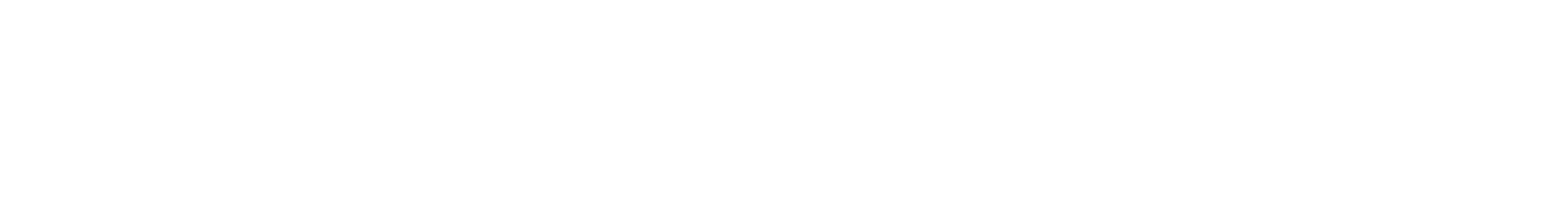

صممت الدرلسة الحالية للاتخدلم قثور الكريب فروت (Citrus paradise) في إزالة أيونات

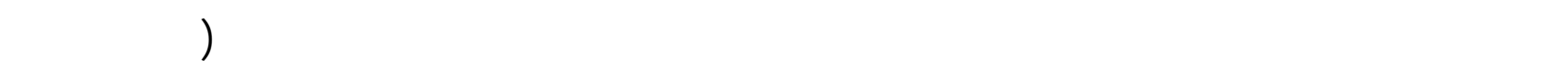

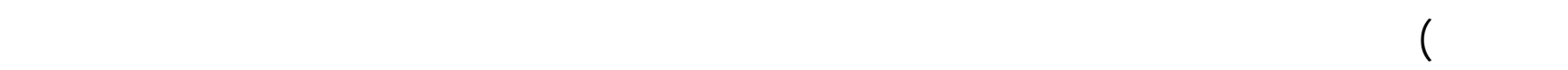

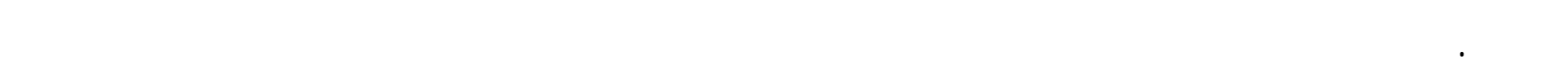

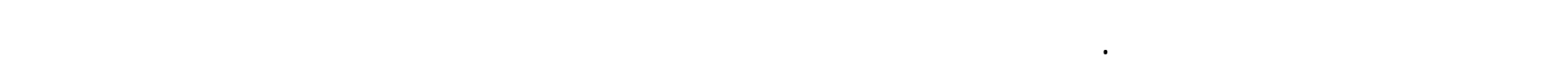

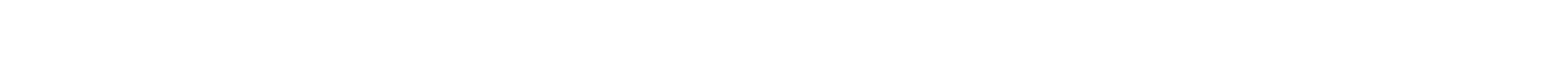


على إزالة أيونات العناصر القيلة تحت الدرلسة. كما بن البحث بأن أعلى قابلية للإزالة كالت للارصاص ثم

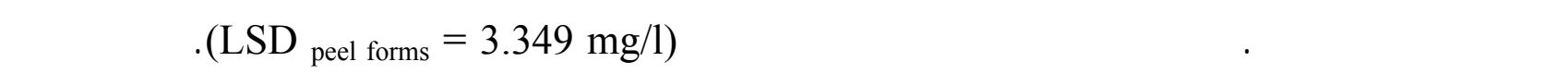

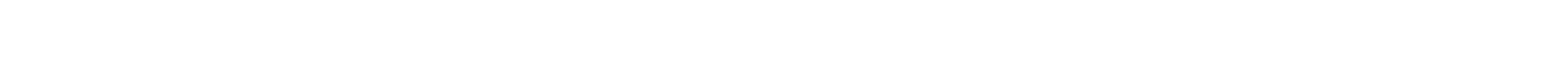

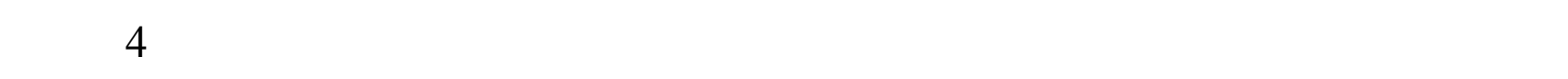

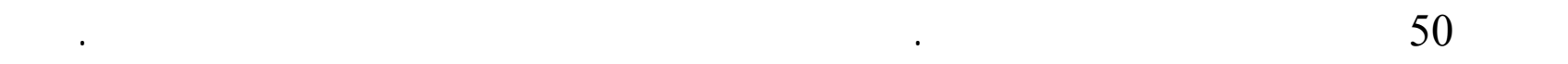

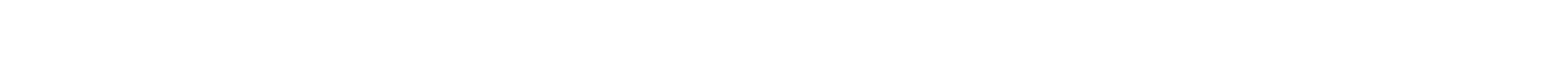
عن مواقع ارتبط العنصر القيل بالقشور.

الهاملت الدالة: قثور الكريب فروت، الامتزاز، الرصاص، النحل، الزك، FTIR.

\section{INTRODUCTION}

The characteristics of industrial wastewater may differ considerably both within and among industries. The impact of industrial discharges would depend not only upon collective characteristics such as biochemical oxygen demand (BOD) and total suspended solids (TSS), but also on their content of specific inorganic and organic substances (Richman, 1997). Heavy metal water pollution represents an important environmental problem due to the possible toxic effects of the metal to both human and environment. The main sources of water contamination with various heavy metals are industrial wastewater (Volesky, 2001; Vijayaraaghavan et al., 2005). Several techniques were applied to remove heavy metal ions from industrial wastewater such as activated carbon adsorption (Singh et al., 2008), chemical precipitation (Ahalya et al., 2005), reverse osmosis (Xia and Liyuan, 2002), electro-dialysis (Ahalya et al., 2005) and ion exchange (Volesky, 2003). However, recently much attention has been focused on possible biological methods for the removal of heavy metals from industrial wastewater (Cho and Kim, 2003), such as microbial biomass (Volesky and Holan, 1995), and biological wastes (Reddad et al., 2002; Saeed et al., 2005; Chockalingam and Subramanian, 2006). These biosorbent materials are characterized as being less expensive, high bio-removal efficiency, metal selective, non sludge generation, possible ion recovery (Tunali and Akar, 2006), and environmentally sound methodology (Husoon, 2011). The technique of plant residues heavy metal ions adsorption was world widely used for wastewater treatment (Montanher et al., 2005) such as peat and nut shells, coconut shells, rice husk, tea waste, peanut hulls, almond shells, peach stones, citrus peels, and many others (Khan et al., 2004). These biosorbent materials consisting mainly of polysaccharides, proteins, and lipids, functional groups that can bind metal ions such as carboxyl, hydroxyl, sulphate, phosphate, and amino groups (Doyurum and Celik, 2006). The importance of any given group of biosorption of a certain metal by a certain biomass depends on several factors such as number of sites of biosorbent material, the accessibility of sites, the chemical state of the site (availability) and affinity between site and metal (binding strength) (Regine and Volesky, 2000). 


\section{MATERIALS AND METHODS}

Examined industrial wastewater samples were collected from the wastewater of pasting unit before wastewater treatment unit, about $20 \mathrm{~cm}$ below the surface in Babylon 2 factory at Al-Waziriya area / Iraq-Baghdad. $500 \mathrm{ml}$ wastewater samples replicated three times per week using pre-sterilized glass containers was collected in four random periods between $8^{\text {th }}$ to $29^{\text {th }}$ June 2011. Each sample was divided into two sub-samples, the first was examined for chemical and physical analysis and the second was employed for bioremoval of lead, copper and zinc ions.

\section{Biosorption capacity of grape fruit peels}

\section{Chemical analysis of industrial wastewater}

Samples of industrial wastewater were collected, 4 times at weekly rate, form pretreatment tank of pasting unit in Babylon 2 factory. Some factors such as $\mathrm{pH}$ and temperature were recorded in situ while the others such as heavy metal content were laboratory assessed.

\section{Metal biosorption tests}

Grape fruit peels were collected from local market and washed thoroughly by deionized distilled water (DDW) and used subsequently in the following examinations:

\section{a. Various grape fruit peel forms}

Three grape fruit peel forms have been used, where the first was as fresh pieces; the second was as dried pieces (using over night oven, $65 \mathrm{C}^{\circ}$ for three days) and finely powdered peels (using grinding agitator) that sieved through $2 \mathrm{~mm}$ stainless steel sieve. All peel forms were examined for bioremoval of lead, copper and zinc from aqueous synthetic solutions under various factors such as $\mathrm{pH}$, temperature and contacting time. Synthetic aqueous metal solution was prepared by taking $20 \mathrm{ml}$ of metal solution $(100 \mathrm{mg} / \mathrm{l})$ of lead, copper or zinc ions and placed into $50 \mathrm{ml}$ volumetric flasks and $\mathrm{pH}$ was adjusted to 5 . About $0.1 \mathrm{~g}$ of grape fruit peels as fresh, dried and powder were added to each flask in three replicated experiments in addition to control (metal ion solution free from peels). All samples were left for almost one hour at $40 \mathrm{C}^{\mathrm{o}}$. Afterwards, each sample was passed through $0.45 \mu \mathrm{m}$ filter paper and metal concentration was determined by using flame atomic adsorption spectroscopy (FAAS) (Zafar et al., 2007), and the technique of Fourier transform infrared analysis was employed to determine the functional groups responsible for metal uptake. (Ahalya et al., 2005).

\section{b. Factors affecting metal bioremoval}

The test carried above was reassessed for the examination of possible effects of different levels of $\mathrm{pH}$, temperature and contact time. For $\mathrm{pH}$, the range of $1-6$, and temperature range was from $10 \mathrm{C}^{\circ}$ to $60 \mathrm{C}^{\mathrm{o}}$ was applied for all metals.

\section{RESULTS AND DISCUSSION}

All of the obtained data were subjected to various biometrical analysis such as the analysis of variance and least significant difference.

\section{Chemical analysis of industrial wastewater}

Table (1) shows mean values of temperature, $\mathrm{pH}, \mathrm{Pb}, \mathrm{Cu}$, and $\mathrm{Zn}$ ions of industrial wastewater. The temperature values were ranged from $31.1 \pm 0.1$ of $1^{\text {st }}$ week sample (8/6/2011) to $31.7 \pm 0.05 \mathrm{C}^{\circ}$ of $4^{\text {th }}$ week sample $(29 / 6 / 2011)$. For $\mathrm{pH}$ data, the highest value $(7.99 \pm 0.3)$ was found in water sample of $1^{\text {st }}$ week $(8 / 6 / 2011)$ while the lowest value 
(7.15 \pm 0.04$)$ was recorded in sample of $4^{\text {th }}$ week. Regarding heavy metals content, the highest content was found in case of $\mathrm{Pb}$ ions that lied from $4.0 \pm 0.7 \mathrm{mg} / \mathrm{l}$ in sample of $2^{\text {nd }}$ week to $5.1 \pm 0.2 \mathrm{mg} / \mathrm{l}$ in $4^{\text {th }}$ week sample, followed by $\mathrm{Zn}$ ions content which was almost of similar levels ranging from $3.9 \pm 1.1 \mathrm{mg} / 1\left(1^{\text {st }}\right.$ week sample $)$ to $4.1 \pm 0.6 \mathrm{mg} / 1\left(4^{\text {th }}\right.$ week sample). In case of $\mathrm{Cu}$ ions, again recorded values were almost similar to each other and varied from $1.1 \pm 0.2 \mathrm{mg} / 1$ ( $3^{\text {rd }}$ week sample) to $1.5 \pm 0.9 \mathrm{mg} / 1$ ( $1^{\text {st }}$ week sample $)$.

\section{Biosorption capacity of grape fruit peels Various peel forms}

Table (2) shows the mean biosorption capacity of grape fruit peels examined at different forms and presented in (Fig. 1). It is clear that grape fruit peel forms showed a significant ability for bio-removing heavy metals from industrial wastewater. However, powdered peels had higher values of bio-removed heavy metal concentrations than those fresh and dried peel pieces (LSD $=3.349$ ). Furthermore, the highest metal concentration $(57.9 \pm 0.9 \mathrm{mg} / \mathrm{l})$ was recorded in case of lead, followed by copper $(34.3 \pm 1.5 \mathrm{mg} / \mathrm{l})$, while the lowest metal concentration $(31.9 \pm 0.8 \mathrm{mg} / \mathrm{l})$ was found in case of zinc (Fig. 1). These values of biosorbed heavy metal concentrations were significantly differed from each other. The highest capacity of grape fruit powdered peels may be due to the surface area of peel particles (Lu et al., 2008) and other environmental factors such as $\mathrm{pH}$ and temperature that may affect the biosorption mechanisms.

\section{Factors affecting biosorption pH}

It is very clear that the increased $\mathrm{pH}$ (Fig. 2) had significant effects $(\mathrm{P} \geq 0.001)$ upon biosorbed metal ions of all heavy metals under test. Also, these heavy metals had varied significantly (Table 3 ) from each other, but the highest biosorption concentrations were recorded for $\mathrm{Pb}$ ions, followed by $\mathrm{Cu}$ while the $\mathrm{Zn}$ ions showed the lowest bio-removed concentrations. However, it seems clearly that $\mathrm{pH} 4$ was the best value for getting optimum bio-removal capacity for lead, copper and zinc ions. Various studies have examined the possible impact of $\mathrm{pH}$ upon heavy metal biosorption of different biosorbent materials and reported similar findings. A recent study (Hashem, 2007) showed that highest lead bioremoved by okra wastes was achieved at $\mathrm{pH}$ range of $4.5-5.5$. Cd ions bioremoved by corn, durian, pummel and banana were found to be high at pH 5 (Eslamzadeh et al., 2004). Optimum $\mathrm{pH}$ value for copper biosorption by marine algae was within a range of $4-6$ (Yu and Kaewsarn, 2002). A study by (Scheiwer and Patil, 2008) had shown that highest lead bioremoved by maize leaf occurred at $\mathrm{pH} 3$. The $\mathrm{pH}$ of aqueous solution plays a significant role in the biosorption process. This is partially due to the fact that $\mathrm{H}^{+}$ions are strongly competing adsorbents. The $\mathrm{pH}$ affects the specification of metal ions and the ionization of surface functional groups (Lu et al., 2008).

\section{Temperature}

Fig. (3) shows the mean biosorbed metal concentration ( $\mathrm{mg} / \mathrm{l})$ by grape fruit peels from solution of lead, copper and zinc at different temperatures. Apparently, increased temperature had significant impacts on bio-removed metal ions (LSD $=5.048 \mathrm{mg} / \mathrm{l}$ ) of these heavy metals resulting in increased biosorption capacity but up to $50 \mathrm{C}^{\circ}$. The highest capacities were found in case of Lead that ranged from $35.1 \pm 0.1 \mathrm{mg} / 1$ to $86.0 \pm 0.2 \mathrm{mg} / \mathrm{l}$, and varied from $30.0 \pm 0.2 \mathrm{mg} / \mathrm{l}$ to $80.9 \pm 1.1 \mathrm{mg} / \mathrm{l}$ and from $26.1 \pm 0.8 \mathrm{mg} / \mathrm{l}$ to $56.1 \pm 1.2$ 
$\mathrm{mg} / \mathrm{l}$ for $\mathrm{Cu}$ and $\mathrm{Zn}$ respectively (Fig. 3). An analysis of variance (Table 4) shows significant differences $(\mathrm{P} \geq 0.001)$ firstly between increased temperatures and secondly between heavy metal ions biosorbed by grape fruit peels.

The current results are similar to those of various studies that examined different biological materials (Reddad et al., 2002; A halya et al., 2005). A recent study (Saikaew and Kaewsarn, 2009) has reported that highest $\mathrm{Cr}$ bio-removed by tassel powder was at $45 \mathrm{C}^{\circ}$ while for $\mathrm{Cd}$ bio-removal, it was $25 \mathrm{C}^{\circ}$. These contracting values may be related to several variables such as biosorbent species, quantity, and other environmental factors. However, the adsorbed species might have enough energy from temperature of the system and subsequently be desorbed at even a faster rate than adsorption rate, or may be due to a linkage of cells in both higher and lower temperature extremes which may reduce the availability surface area of contact (Zvinowwanda et al., 2009).

\section{Contact time}

The impacts of various contact times upon all $\mathrm{Pb}, \mathrm{Cu}$, and $\mathrm{Zn}$ bio-removed by grape fruit peels (Fig. 4) are quite obvious but nevertheless, one hour contact time seems to be optimum in case of all heavy metals examined in this study. However, highest capacities $(18.1 \pm 1.1 \mathrm{mg} / 1$ to $93.5 \pm 0.5 \mathrm{mg} / \mathrm{l})$ were recorded for $\mathrm{Pb}$ biosorption, followed by those $(23.8 \pm 1.4 \mathrm{mg} / \mathrm{l}$ to $89.9 \pm 0.6 \mathrm{mg} / \mathrm{l})$ of $\mathrm{Cu}$ and $(17.0 \pm 0.75 \mathrm{mg} / 1$ to $76.1 \pm 1.83 \mathrm{mg} / \mathrm{l}) \mathrm{Zn}$ (Fig. 4). The analysis of variance of contact time effects shows significant differences $(\mathrm{P} \geq$ 0.001 ) between firstly increased times and secondly between heavy metals biosorbed by grape fruit peels (Table 5).

The obtained results agreed with other studies (Cordo et al., 2004; A1-Pachachi, 2006; Husoon, 2011). However another work (Habib et al., 2007), has reported that the required contact time for the best copper bio-removed by orange peels was less than one hour (40 minutes).

Fig. (5) shows the spectra of the biosorbent of grape fruit peel after exposure to heavy metals solution for each metal. The FTIR spectra represent broad bands at $3365-3423 \mathrm{~cm}^{-1}$, giving -OH and -NH groups. Bands observed at about $2850-2956 \mathrm{~cm}^{-1}$ assigned to the $-\mathrm{CH}$ groups, while the bands at $1660-1734 \mathrm{~cm}^{-1}$ represent $-\mathrm{COO}$, the bands at $1640-1653 \mathrm{~cm}^{-1}$ are due to $-\mathrm{COOH}$ groups and the peaks at $1226-1400 \mathrm{~cm}^{-1}$ represent the $-\mathrm{C}=\mathrm{O}$ groups. However, the peaks at $1049-1200 \mathrm{~cm}^{-1}$ are corresponding to the $-\mathrm{C}-\mathrm{O}$ stretching, and peaks at $850-894 \mathrm{~cm}^{-1}$ are probably caused by $-\mathrm{C}-\mathrm{N}$ bonding in amines. The previous results showed that the chemical groups that bind the metals are hydroxyl, carboxyl, amide and amine groups. This explains the reason behind the binding sites as they are nearly associated with the same sites. Also, this may indicate that bond stretching occurred to a less extent due to the exchange of hydrogen ions with lead, copper and zinc, and subsequently peak absorbance was attenuated (Kamsonlian et al., 2011).

From the current work, it seems clear that the ability of grape fruit peels was significantly effective for the removal of $\mathrm{Pb}, \mathrm{Cu}$, and $\mathrm{Zn}$ ions from industrial wastewater due to the high affinity between the metal ions and the binding sites of the biosorbent. As it had been reported for various biosorbent plant materials (Khan et al., 2004; Lu et al., 2008; Husoon, 2011) and would successfully be applied for various heavy metals from industrial wastewater since it seems environmentally sound. 
Table 1: Mean value \pm standard deviation of several water variables

\begin{tabular}{|l|c|c|c|c|}
\hline \multirow{2}{*}{ Variables } & \multicolumn{4}{|c|}{ Mean value \pm SD of some industrial wastewater components } \\
\cline { 2 - 5 } & $\begin{array}{c}\mathbf{1}^{\text {st }} \text { week } \\
\mathbf{8 / 6 / 2 0 1 1}\end{array}$ & $\begin{array}{c}\mathbf{2}^{\text {nd }} \text { week } \\
\mathbf{1 5} / \mathbf{6} / \mathbf{2 0 1 1}\end{array}$ & $\begin{array}{c}\mathbf{3}^{\text {rd }} \text { week } \\
\mathbf{2 2}^{2 / 6 / 2011}\end{array}$ & $\begin{array}{c}\mathbf{4}^{\text {th }} \text { week } \\
\mathbf{2 9 / 6 / 2 0 1 1}\end{array}$ \\
\hline Temp. $\mathrm{C}^{\circ}$ & $30.1 \pm 0.1$ & $31.0 \pm 0.1$ & $30.3 \pm 0.2$ & $31.7 \pm 0.05$ \\
\hline $\mathrm{pH}$ & $7.99 \pm 0.3$ & $7.4 \pm 0.4$ & $7.37 \pm 0.09$ & $7.15 \pm 0.04$ \\
\hline $\mathrm{Pb}(\mathrm{mg} / \mathrm{l})$ & $4.1 \pm 0.74$ & $4.0 \pm 0.7$ & $4.6 \pm 0.7$ & $5.1 \pm 0.2$ \\
\hline $\mathrm{Cu}(\mathrm{mg} / \mathrm{l})$ & $1.5 \pm 0.9$ & $1.2 \pm 0.2$ & $1.1 \pm 0.2$ & $1.4 \pm 0.22$ \\
\hline $\mathrm{Zn}(\mathrm{mg} / \mathrm{l})$ & $3.9 \pm 1.1$ & $4.0 \pm 0.4$ & $4.1 \pm 0.4$ & $4.1 \pm 0.6$ \\
\hline
\end{tabular}

Table 2: Mean Lead, Copper and Zinc concentrations percentage (mg/l) biosorbed by various grape fruit peel forms

\begin{tabular}{|c|c|c|c|}
\hline \multirow{2}{*}{$\begin{array}{l}\text { Grape fruit peel } \\
\text { forms }\end{array}$} & \multicolumn{3}{|c|}{$\begin{array}{l}\text { Mean metal biosorbed concentration } \\
(\mathrm{mg} / \mathrm{l}) \pm \mathrm{SD}\end{array}$} \\
\hline & Lead \% & Copper \% & Zinc \% \\
\hline Dried pieces & $36.7 \pm 0.6$ & $22.9 \pm 0.9$ & $20.8 \pm 0.8$ \\
\hline Fresh pieces & $47.8 \pm 1.6$ & $30.1 \pm 1.1$ & $28.1 \pm 1.2$ \\
\hline Powdered & $57.9 \pm 0.9$ & $34.3 \pm 1.5$ & $31.9 \pm 0.8$ \\
\hline LSD & \multicolumn{3}{|c|}{3.349} \\
\hline
\end{tabular}

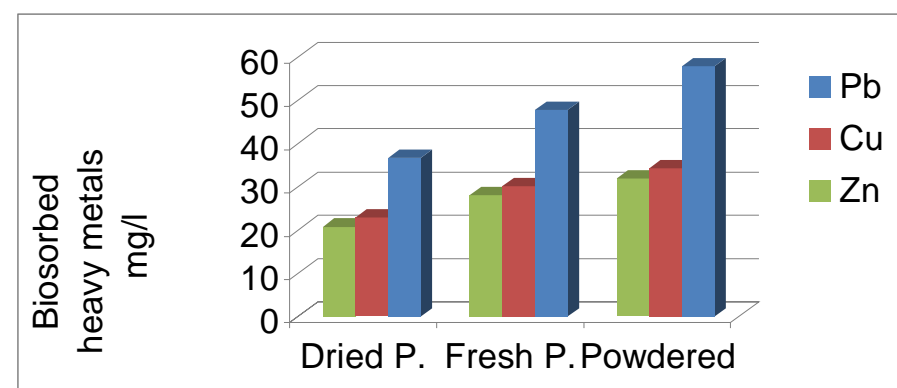

Peel Forms

Fig. 1: Mean biosorbed metal concentration (mg/l) by grape fruit various peel forms 


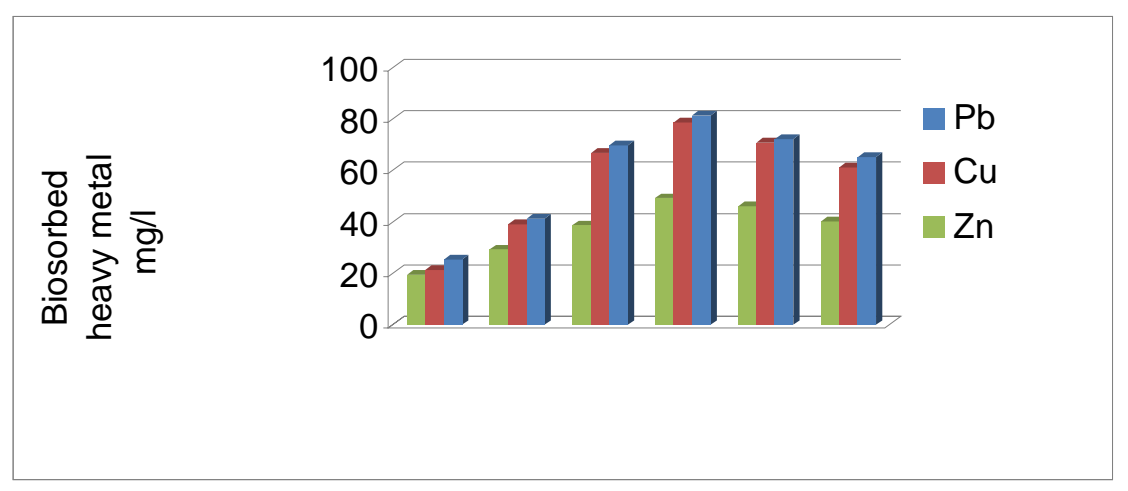

Fig. 2: Mean biosorbed metal concentration (mg/l) by grape fruit peels from solution of $\mathrm{Pb}, \mathrm{Cu}$ and $\mathrm{Zn}$ at different $\mathrm{pH}$ values

Table 3: Analysis of variance of mean $\mathrm{Pb}, \mathrm{Cu}$, and $\mathrm{Zn}$ concentration biosorbed by grape fruit peels at six $\mathrm{pH}$ levels

\begin{tabular}{|c|c|c|c|c|}
\hline $\begin{array}{c}\text { Source of } \\
\text { variance }\end{array}$ & df & SS & MS & Probability \\
\hline Replications & 2 & 0.827 & 0.484 & N.S. \\
\hline Treatment & 17 & 5543.74 & 326.73 & 0.001 \\
\hline Metal (M) & 2 & 838.94 & 419.55 & 0.001 \\
\hline $\mathrm{pH}(\mathrm{P})$ & 5 & 3712.31 & 781.17 & 0.001 \\
\hline $\mathrm{M} \times \mathrm{P}$ & 10 & 1099.5 & 109.95 & 0.001 \\
\hline Error & 34 & 49.998 & 3.981 & 0.001 \\
\hline Total & \multicolumn{5}{|c|}{53} \\
\hline
\end{tabular}

$\mathrm{df}=$ degree of freedom, $\mathrm{ss}=$ sum square, $\mathrm{ms}=$ mean square

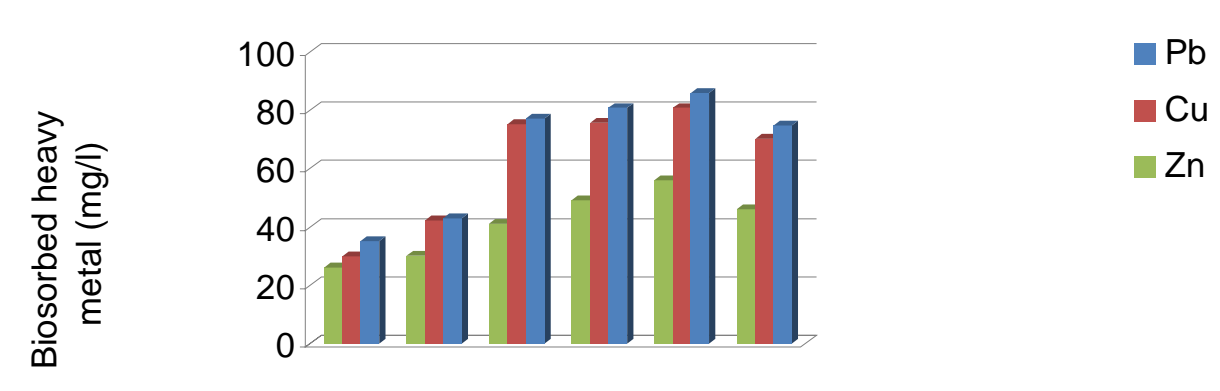

Fig. 3: Mean biosorbed metal concentration (mg/l) by grape fruit peels from solution of $\mathrm{Pb}, \mathrm{Cu}$ and $\mathrm{Zn}$ at different temperatures 
Table 4: Analysis of variance of mean $\mathrm{Pb}, \mathrm{Cu}$, and $\mathrm{Zn}$ concentrations biosorbed by grape fruit peels at six temperature values

\begin{tabular}{|c|c|c|c|c|}
\hline $\begin{array}{c}\text { Source of } \\
\text { variance }\end{array}$ & df & SS & MS & Probability \\
\hline Replications & 2 & 8.9 & 4.7 & N.S. \\
\hline Treatment & 17 & 9499.4 & 678.53 & 0.001 \\
\hline Metal $(\mathrm{M})$ & 2 & 682.4 & 344.7 & 0.001 \\
\hline Temp (T) & 5 & 8209.3 & 1644.2 & 0.001 \\
\hline $\mathrm{M} \times \mathrm{T}$ & 10 & 609.8 & 60.98 & 0.001 \\
\hline Error & 34 & 73.7 & 2.978 & 0.001 \\
\hline Total & \multicolumn{5}{|c|}{53} \\
\hline
\end{tabular}

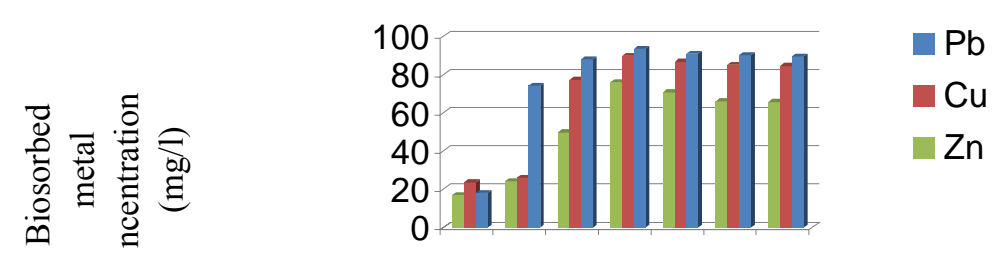

Fig. 4: Mean biosorbed metal concentration (mg/l) by grape fruit peels from solution of $\mathrm{Pb}$, different contact time

Table 5: Analysis of variance of mean $\mathrm{Pb}, \mathrm{Cu}$, and $\mathrm{Zn}$ concentration biosorbed by grape fruit peels with different contact time

\begin{tabular}{|c|c|c|c|c|}
\hline $\begin{array}{c}\text { Source of } \\
\text { variance }\end{array}$ & df & SS & MS & Probability \\
\hline Replications & 2 & 2.382 & 1.2 & N.S. \\
\hline Treatment & 20 & 21315.63 & 1065.272 & 0.001 \\
\hline Metal $(\mathrm{M})$ & 2 & 1355.1 & 676.8 & 0.001 \\
\hline $\mathrm{C}^{*}$ time $(\mathrm{T})$ & 6 & 19528.44 & 3255.12 & 0.001 \\
\hline $\mathrm{M} \times \mathrm{I}$ & 12 & 424.1 & 35.33 & 0.001 \\
\hline Error & 40 & 119.62 & 3.01 & 0.001 \\
\hline Total & \multicolumn{5}{|c|}{62} \\
\hline
\end{tabular}

*contact 


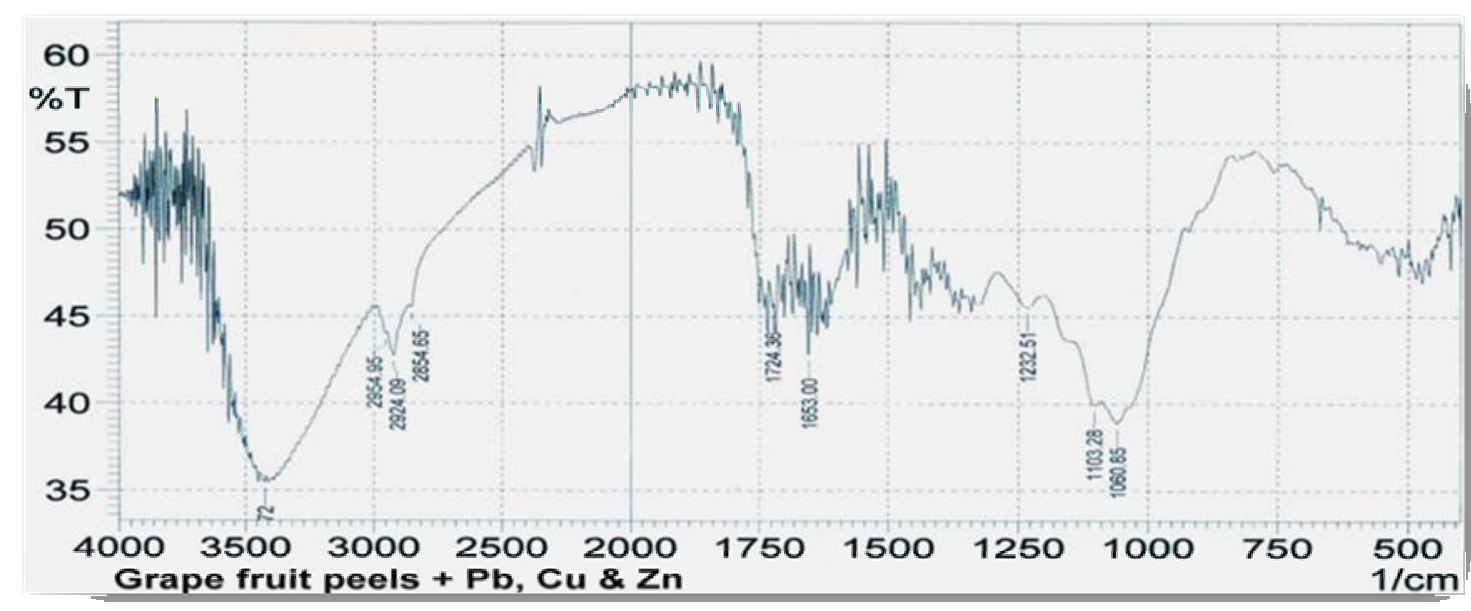

Fig. 5: FTIR analysis of grape fruit peels in synthetic solution

REFERENCES

Ahalya, N.; Ramachandra, T.V.; Kanamadi, R.D. (2005). Biosorption of chromium (VI) from aqueous solution by the husk of Bengal gram (Cicer arientinum). Elec. J. Bio. Technol., 18(3), 44-48.

Al-pachachi, U.S. (2006). Bioremoval of zinc by cell wall of bacteria bacillus subtilis. M.Sc. Thesis, College of Science, University of Baghdad, Iraq.

Cho, D.H.; Kim, E.Y. (2003). Characterization of $\mathrm{Pb}^{+2}$ biosorption from aqueous solution by Rhodotorula glutinis bioprocess. Bio. Syst. Eng., 25, 271-277.

Chockalingam, E.; Subramanian, S. (2006). Studies on removal of metal ions and sulphate reduction using rice husk and desulfotomaculum nigrificans with reference to remediation of acid mine drainage. Chemosphere, 62, 699-708.

Cordo, B.; Loderio, P.; Herrero, R.; de Vicente, M.E.S. (2004). Biosorption of cadmium by Fucus spiralis. Environ. Chem; 1,180-187

Doyurum, S.; Celik, A. (2006). Pb (II) and Cd (II) removal from aqueous solution by olive cake. J. Hazard Mater., 138 (1), 22-28.

Eslamzadeh, T.; Nasernejad, B.; Pour, B.B. (2004). Removal of heavy metals from aqueous solution by carrot residues. Iran. J.Sci. Technol. Trans., 28(A),16-19.

Habib, A.; Nazrul, I.; Anarul, I.; Shafiqul Alam, A. M. (2007). Removal of copper from aqueous solution using orange peel, sawdust and bagasse. Pak. J. Anal. Environ. Chem.; 8 (1-2), 21-25.

Hashem, M. (2007). Adsorption of lead from aqueous solution by okra wastes. Int. J. Phys. Sci., 2(7), 178-184.

Husoon, Z.A. (2011). Biotreatment of some heavy metals in industrial wastewater. Ph.D. Thesis, College of Science, University of Baghdad, Iraq.

Kamsonlian, S.; Suresh, S.; Majumder, C.; Chand, S. (2011). Characterization of banana and orange peels: Biosorption mechanism. Intern. J. Sci. Techn. Manag., 2(4), 1-7.

Khan, N.A.; Ibrahim, S.; Subramanian, P. (2004). Elimination of heavy metals from wastewater using agricultural wastes as adsorbents. Malaysian J. Sci., 23, 43-51. 
Lu, D.; Cao, Q.; Li, X.; Cao, X.; Luo, F.; Shao, W. (2008). Kinetics and equilibrium of Cu (II) adsorption onto chemically modified orange peel cellulose biosorbents. Hydrometallurgy, 64, 1122-1127.

Montanher, S.F.; Oliveira, E.A.; Rollengerg, M.C. (2005). Removal of metal ions from aqueous solution by sorption onto rice bran. J. Hazard. Mater.117, 207-211.

Reddad, Z.; Gerente, C.; Andres, Y.; Pierre, L.C. (2002). Adsorption of several metal ions onto a low cost biosorbent: Kinetic and Equilibrium Studies. Environ. Sci. Technol., 36(9), 2067-2073.

Regine, H.; Volesky, B. (2000). Biosorption: a solution to pollution. Intern. Micro. Bio. 3, 17-24.

Richman, M.I. (1997). Water pollution. Wastewater, 5(2), 24-29.

Saeed, A.; Iqbal, M.; Akhtar, M.W. (2005). Removal and recovery of lead (II) from single and multi-metal $(\mathrm{Cd}, \mathrm{Cu}, \mathrm{Ni}, \mathrm{Zn})$ solutions by crop milling waste (black gram husk). Hazar. Mater., 117, 65-73.

Saikaew, W.; Kaewsarn, P. (2009). Cadmium ion removal using biosorbents derived from fruit peel wastes. Songklanakarin J. Sci. Technol. 31(5), 547-554.

Scheiwer, S.; Patil, S.B. (2008). Pectin-rich fruit wastes as biosorbents for heavy metal removal: Equilibrium and Kinetics. Bio. Res. Technol. 99, 1896-1903.

Singh, C.K.; Sahu, J.N.; Mahalik, K.K.; Mohanty, C.R.; Mohan, B.R.; Meikap, B.C. (2008). Studies on the removal of $\mathrm{Pb}$ (II) from wastewater by activated carbon developed from Tamarind wood activated with sulphuric acid. J. Hazard. Mater.,153, 221228.

Tunali, S.; Akar, T. (2006). Biosorption properties of Botrytis cinerea biomass. J. Hazard. Mater., 131, 137-145.

Vijayaraaghavan, K.J.; Jegan, K.P.; Velan, M. (2005). Batch and column removal of copper from aqueous solution using a brown marine alga. J. Chem. Eng., 106,177-184.

Volesky, B. (2001). Detoxification of metal-bearing effluents: biosorption for the next century. Hydrometallurgy, 59, 203-216.

Volesky, B. (2003). "Sorption and Biosorption". Sorbex. Inc. St. Lambert (Montreal). Quebec, Canada.

Volesky, B.; Holan, Z.R. (1995). Biosorption of heavy metals. Bio. Technol. Prog., 11, 235250.

Xia, Y.; Liyuan, C. (2002). Study of gelatinous supports for immobilizing inactivated cells of Rhizopus oligosporus to prepare biosorbent for lead ions. Intern. J. Environ. Studies, 5(16), 33-38.

$\mathrm{Yu}$, Q.; Kaewsarn, P. (2002). Biosorption of copper (II) from aqueous solution by pretreated biomass of marine alga Padina sp. Chemosp., 47, 1081-1085.

Zafar, M.N.; Nadeem, R.; Hanif, M.A. (2007): Biosorption of nickel from protonated rice bran. J. Hazard. Mater., 143, 478-485.

Zvinowwanda, C.M.; Okonko, J.O.; Agyei, N.M.; Shabalala, P.N. (2009). Physiochemical characterization of maize tassel adsorbent: Part I .Surface texture, microstructure and thermal stability. J. Applied Poly. Sci., 2, 1923-1930. 